\title{
ORGANOCHLORINE PESTICIDE RES
IN BED SEDIMENTS OF THE SAN JOAQUIN RIVER \\ AND ITS TRIBUTARY STREAMS CALIFORNIA
}

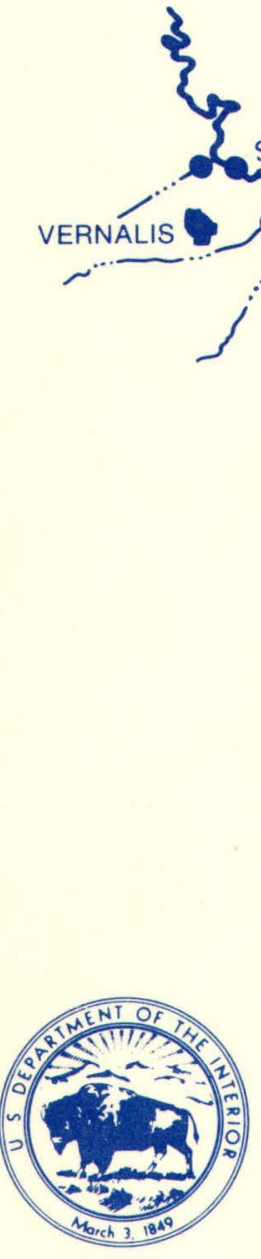

U.S. GEOLOGICAL SURVEY Open-File Report 87-531
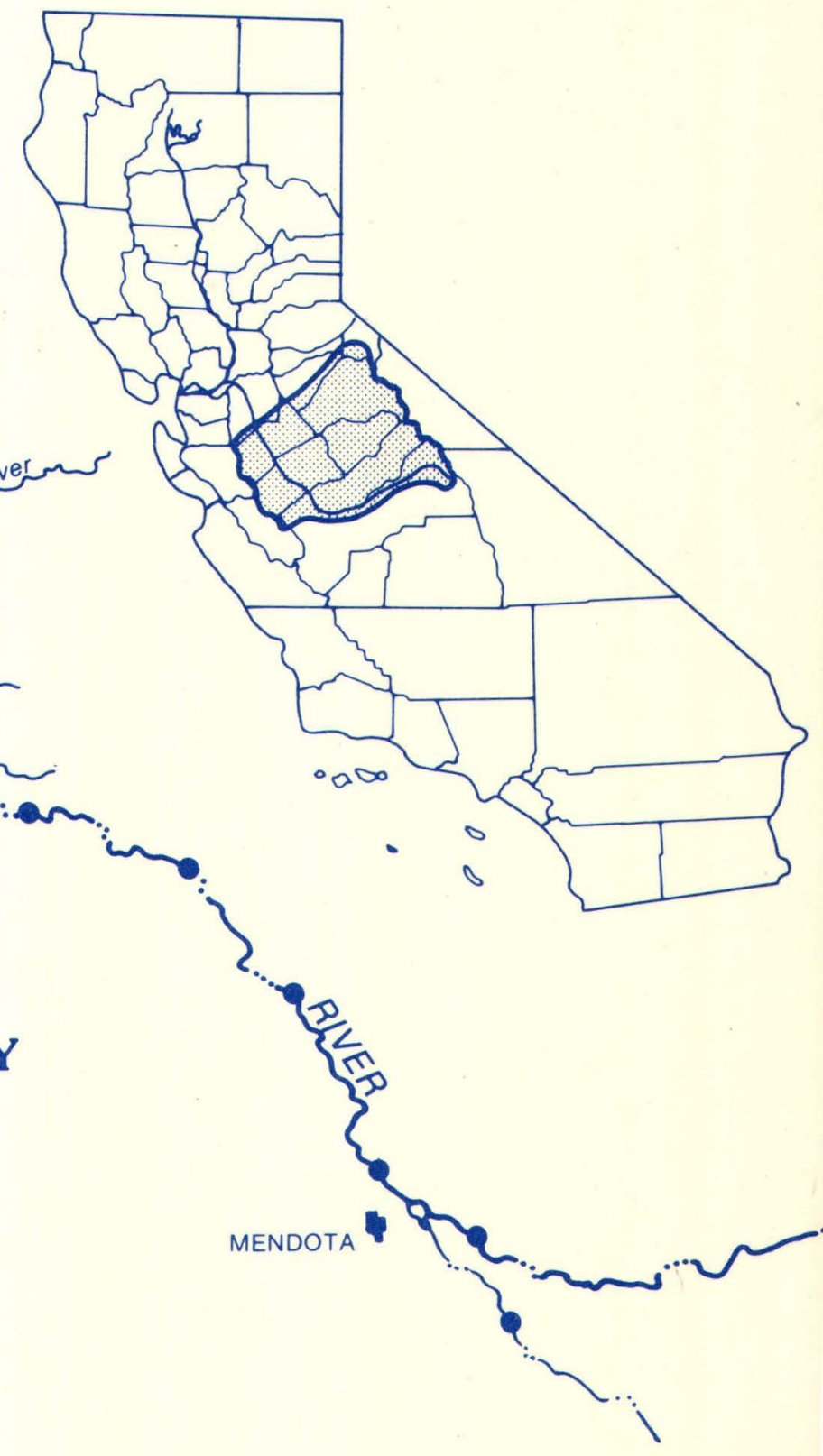

Prepared in cooperation with the SAN JOAQUIN VALLEY DRAINAGE PROGRAM 
This report was prepared by the U.S. Geological Survey in cooperation with the San Joaquin Valley Drainage Program.

The San Joaquin Valley Drainage Program was established in mid-1984 and is a cooperative effort of the U.S. Bureau of Reclamation, U.S. Fish and Wildlife Service, U.S. Geological Survey, California Department of Fish and Game, and California Department of Water Resources. The purposes of the Program are to investigate the problems associated with the drainage of agricultural lands in the San Joaquin Valley and to develop solutions to those problems. Consistent with these purposes, program objectives address the following key areas: (1) Public health, (2) surface- and ground-water resources, (3) agricultural productivity, and (4) fish and wildlife resources.

Inquiries concerning the San Joaquin Valley Drainage Program may be directed to:

San Joaquin Valley Drainage Program

Federal-State Interagency Study Team

2800 Cottage Way, Room W-2143

Sacramento, California 95825-1898 
ORGANOCHLORINE PESTICIDE RESIDUES IN BED SEDIMENTS OF THE

SAN JOAQUIN RIVER AND ITS TRIBUTARY STREAMS, CALIFORNIA

By Robert J. Gilliom and Daphne G. Clifton

U.S. GEOLOGICAL SURVEY

Open-File Report 87-531

Prepared in cooperation with the

SAN JOAQUIN VALLEY DRAINAGE PROGRAM

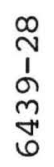


DEPARTMENT OF THE INTERIOR

DONALD PAUL HODEL, Secretary

U.S. GEOLOGICAL SURVEY

Dallas L. Peck, Director

For additional information write to:

District Chief

U.S. Geological Survey

Federal Building, Room W-2234

2800 Cottage Way

Sacramento, CA 95825
Copies of this report may be purchased from:

U.S. Geological Survey Books and Open-File Reports Box 25425

Building 810, Federal Center Denver, CO 80225 


\section{CONTENTS}

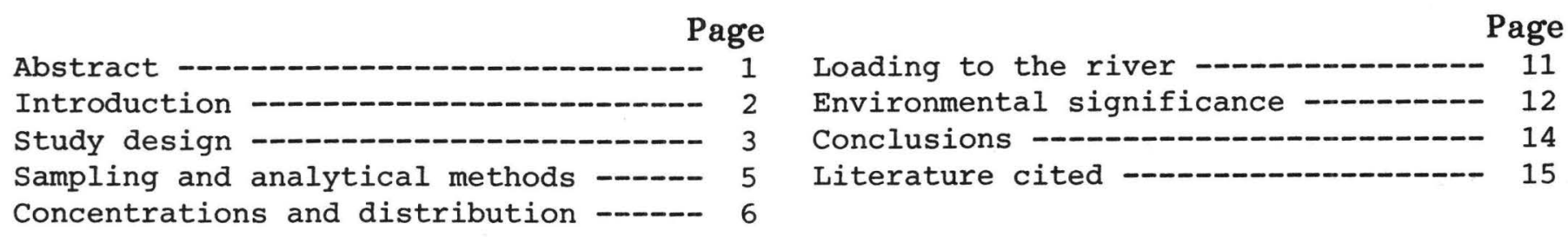

\section{ILLUSTRATIONS}

Figure 1. Map showing location of study sites 2-4. Graphs showing:

2. Relation between DDE concentrations in bed sediments and total organic carbon -- 9

3. Relation between total organic carbon and $<62-\mu \mathrm{m}$ size fraction

4. Distribution of DDE concentrations after standardizing by total organic carbon

\section{TABLES}

Table 1. Study site names

2. Concentrations of organochlorine pesticides detected in duplicate samples split in the field and submitted blind to

3. Concentrations of organochlorine pesticides detected in bed sediments -

4. Streamflow and bed- and suspended-sediment characteristics --_--_----- 8

5. Correlation matrix for DDD, DDE, DDT, and dieldrin at all 24 sites

6. Estimated tributary loads of DDD, DDE, DDT, and dieldrin relative to the estimated load near Vernalis

7. Comparison of estimated water concentrations of detected organochlorine pesticides to water-quality criteria for aquatic life 


\section{CONVERSION FACTORS}

Metric (SI) units are used in this report. For readers who prefer to use inchpound units, the conversion factors for the terms used in this report are listed below.

\section{Multiply}

ha (hectares)

$\mathrm{m}$ (meter)

$\mathrm{m}^{3} / \mathrm{s}$ (cubic meter per second)

$\mathrm{km}$ (kilometer)

$\mathrm{kg}$ (kilogram)

$\mathrm{cm}$ (centimeter)
$2 . \frac{\mathrm{By}}{471}$
3.281
35.31
0.6214
2.205
0.394

\begin{tabular}{l} 
To Obtain \\
\hline acre \\
foot \\
cubic foot \\
per second \\
mile \\
pound \\
inch
\end{tabular}

\section{ABBREVIATIONS USED}

$\begin{array}{ll}\mu \mathrm{m} & \text { micrometer } \\ \mu \mathrm{g} / \mathrm{L} & \text { microgram per liter } \\ \mathrm{mg} / \mathrm{L} & \text { milligram per liter } \\ \mu \mathrm{g} / \mathrm{kg} & \text { microgram per kilogram } \\ \mathrm{kg} / \mathrm{d} & \text { kilogram per day }\end{array}$

\section{TRADE NAMES}

The use of brand or trade names in this report is for identification purposes and does not imply endorsement by the U.S. Geological Survey. 


\section{ORGANOCHLORINE PESTICIDE RESIDUES IN BED SEDIMENTS \\ OF THE SAN JOAQUIN RIVER AND ITS \\ TRIBUTARY STREAMS, CALIFORNIA}

By Robert J. Gilliom and Daphne G. Clifton

\begin{abstract}
The distribution and concentrations of organochlorine pesticide residues in bed sediments were assessed from samples collected at 24 sites in the San Joaquin River and its tributaries in the San Joaquin Valley, California. Sampling was designed to collect the finest grained bed sediments present in the vicinity of each site. One or more of the 14 pesticides analyzed were detected at every site. Pesticides detected at one or more sites were chlordane, DDD, DDE, DDT, dieldrin, endosulfan, mirex, and toxaphene. Pesticides not detected were endrin, heptachlor, heptachlor epoxide, lindane, methoxychlor, and perthane. The most frequently detected pesticides were DDD (83 percent of sites), DDE (all sites), DDT (33 percent of sites), and dieldrin (58 percent of sites).
\end{abstract}

Maximum concentrations of these pesticides, which were correlated with each other and with the amount of organic carbon in the sample, were DDD, 260 micrograms per kilogram; DDE, 430 micrograms per kilogram; DDT, 420 micrograms per kilogram; and dieldrin, 8.9 micrograms per kilogram. Six small tributary streams that drain agricultural areas west of the San Joaquin River had the highest concentrations.

Water concentrations and loads were estimated for each pesticide from its concentration in bed sediments, the concentration of suspended sediment, and streamflow. Estimated loadings of DDD, DDE, DDT, and dieldrin from tributaries to the San Joaquin River indicate that most of the loading to the river at the time of the study was probably from the westside tributaries. Estimated water concentrations exceeded the aquatic-life criterion for $E D D T$ (the sum of DDD, DDE, and DDT) of 0.001 microgram per liter at 9 of the 24 sites sampled. Five of the nine sites are westside tributaries and one is the San Joaquin River near Vernalis. 


\section{INTRODUCTION}

The 2.4 million ha of land drained by the San Joaquin River includes about 0.8 million ha of irrigated farmland, located mainly on the valley floor along the river and the lower parts of its tributaries. Pesticide use on this farmland has been heavy and diverse. In 1977, for example, about 6.8 million $\mathrm{kg}$ of active ingredients of restricted-use pesticides were applied in Madera, Merced, and Stanislaus Counties, which encompass most of the farmland in the San Joaquin River drainage basin (California Department of Food and Agriculture, 1977). In 1982, about 21 million $\mathrm{kg}$ of active ingredients were applied in the entire San Joaquin Valley, of which about one-half is included in the San Joaquin River drainage (University of California, Davis, written commun., 1987; data were not available for all individual counties). More than 400 different active pesticide ingredients were included in this use. The potential adverse effects of these pesticides on the fish, wildlife, and people who use the San Joaquin River has been a long-standing concern (Lavenda, 1982).

Different pesticides pose varying degrees and types of risk to water quality (U.S. Environmental Protection Agency, 1985; 1986). Some pesticides, such as parathion and other organophosphate compounds, are highly soluble in water and relatively short-lived in the environment. These types of pesticides generally may cause short-term problems when present at high concentrations. On the other extreme, organochlorine compounds, such as chlordane and DDT, are only slightly soluble in water, but their residues may persist in soil, aquatic sediments, and organisms for years after they are applied. The main environmental threat of organochlorine residues is their tendency to concentrate in the tissues of organisms.

The use of most organochlorine pesticides on farms in the United States has been greatly reduced or eliminated since the early 1970's (Gilliom, et al., 1985), when pesticide-use records were first kept in California (Mischke, et al., 1985). Therefore, past use of these pesticides cannot be quantitatively linked to present-day occurrence of residues in the environment. However, we can proceed with the general knowledge that use of these pesticides, particularly DDT (Mischke, et al., 1985) was widespread in intensively farmed areas like the San Joaquin valley. Indeed, some of their residues still persist at troublesome levels in fish taken from the San Joaquin River. Saiki and Schmitt (1986) recently confirmed earlier studies by Hunt (1964), Bailey and Hannum (1967), LaCaro, et al. (1982), and LaCaro (1983), which documented accumulation of organochlorine residues in fish of the lower San Joaquin River. In 1981, Saiki and Schmitt (1986) collected two samples of common carp from the San Joaquin River which had concentrations of EDDT (the sum of DDD, DDE, and DDT) exceeding the recommended safe level of $1.0 \mathrm{mg} / \mathrm{kg}$ wet weight (National Academy of Sciences and National Academy of Engineering, 1973). Fish from one site also contained toxaphene at concentrations exceeding the recommended safe level of $0.1 \mathrm{mg} / \mathrm{kg}$ wet weight. More recent data reported by Linn, et al. (1986) for 1985 indicate similar concentrations. The presence of organochlorine residues in the San Joaquin River system remains a concern.

The main purpose of the present study is to assess the distribution and concentrations of organochlorine pesticide residues in bed sediments of the San Joaquin River and its tributaries. 
Because of their low solubility and tendency to associate with particulate matter in aquatic systems, organochlorine residues persist in bed sediments of rivers and streams and are replenished or diluted by additions of new soil material eroded from agricultural fields. The bed sediments of rivers and streams are a useful part of the aquatic system to sample as an indicator of the distribution and relative levels of organochlorines at many locations throughout a drainage basin. In addition, bedsediment data can be used to make preliminary estimates of potential water concentrations and the relative importance of sources of pesticides to the river. Findings from this type of reconnaissance study can then be used to efficiently design more detailed studies. This study was done as part of a comprehensive investigation by the U.S. Geological survey of the hydrology and geochemistry of the San Joaquin Valley in cooperation with the San Joaquin Valley Drainage Program.

\section{STUDY DESIGN}

Below the headwaters of the San Joaquin River in the Sierra Nevada, the river extends $309 \mathrm{~km}$ from Friant Dam in the foothills, to Vernalis, just upstream from backwater influence of the Sacramento-San Joaquin Delta (fig. 1). The first $105 \mathrm{~km}$ of river between Friant Dam and Mendota generally have intermittent flow and often no river water reaches Mendota Pool near Mendota. Most of the next $108 \mathrm{~km}$ of river between Mendota and Stevinson is also intermittent. Flow in the remaining $97 \mathrm{~km}$ of river from Stevinson to Vernalis is perennial and increases downstream as irrigation-return flows and the Merced, Tuolumne, and Stanislaus Rivers enter from the east. This study focuses on the San Joaquin River between Mendota and Vernalis and its tributaries within that $205 \mathrm{~km}$ reach.
Bed sediments were sampled for pesticide analyses at 24 sites distributed among six different parts of the river system (table 1 and fig. 1 ).

Mendota Pool Area (4 sites).--Included are one site on Fresno Slough upstream from Mendota Pool (site 12) and three sites on the San Joaquin River downstream from Mendota Pool where perennial flow is maintained by release of water from the pool (sites 14, 16, and 18).

\section{Intermittent San Joaquin River} ( 3 sites).--Two sites are on the san Joaquin River between State Highway 152 and Bear Creek (sites 21 and 22) and one site is on Mariposa Slough before it enters the river from the east (site 25).

Salt and Mud Sloughs (4 sites).--There is one site on Salt Slough (site 2), one site on Mud Slough (site 4), and one site on each of two Mud Slough tributaries, Santa Fe Canal (site 29) and Los Banos Creek (site 32 ).

Eastside Tributaries (4 sites).--The perennial eastside tributaries are the Merced River (site 5), the Tuolumne River (site 8), and the Stanislaus River (site 10). Bear Creek (site 27) is an intermittent eastside tributary.

Westside Tributaries (6 sites).--Sites $34,35,36,39,40$, and 42 are intermittent streams and canal wasteways that carry agricultural surface runoff from the western part of the lower river valley to the San Joaquin River.

Perennial San Joaquin River (3 sites).-Sites on the San Joaquin River include one just upstream from salt and Mud Sloughs (site 1), one between where Salt and Mud Slough enter the river (site 3 ), and one near Vernalis (site 11). 


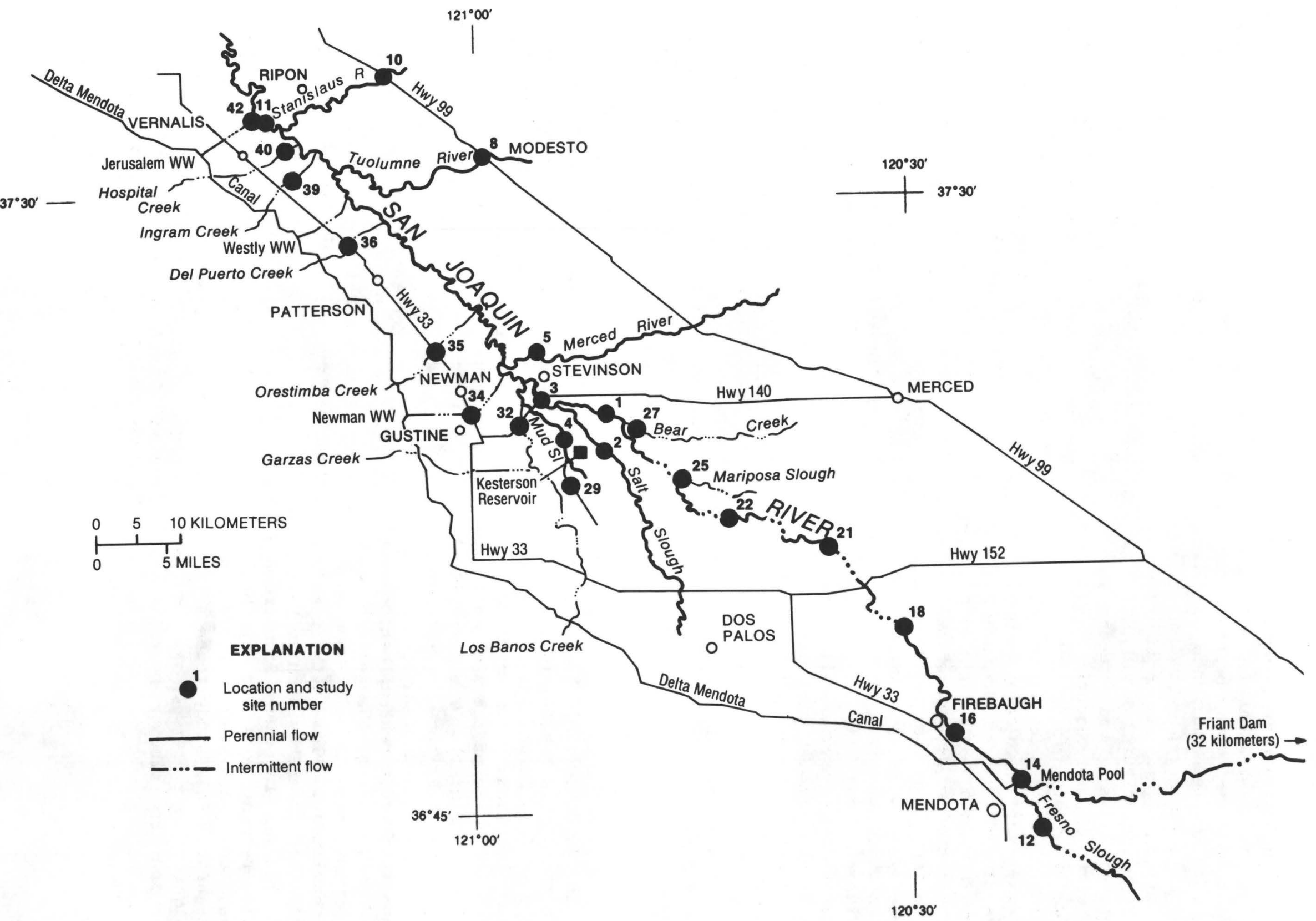

FIGURE 1. -- Location of study sites. 
Table 1.--Study site names

\begin{tabular}{l}
\hline Site \\
No.
\end{tabular}

\section{Mendota Pool Area}

12

14

16

18

21
Fresno Slough near State Highway 180 San Joaquin River below Mendota Pool San Joaquin River near Firebaugh

San Joaquin River near Dos Palos

\section{Intermittent San Joaquin River}

San Joaquin River near Washington Bridge San Joaquin River near Turner Island Mariposa Slough

\section{Salt and Mud Sloughs}

Salt Slough at State Highway 165

Mud Slough near Gustine

Santa Fe Canal

Los Banos Creek near State Highway 140

\section{Eastside Tributaries}

Merced River near Stevinson

Tuolumne River at Modesto

Stanislaus River at Ripon

Bear Creek near Stevinson

\section{Westside Tributaries}

Newman Wasteway near State Highway 33 Orestimba Creek near State Highway 33

Del Puerto Creek near State Highway 33

Ingram Creek near River Road

Hospital Creek near River Road

Jerusalem Wasteway near Kasson Road

\section{Perennial San Joaquin River}

San Joaquin River near Stevinson

San Joaquin River at Fremont Ford Bridge

San Joaquin River near Vernalis

The sample-collection strategy at each site was designed to obtain a sample of recently deposited, fine-grained sediment. If successful, such a bed-sediment sample would resemble as closely as possible the type of particulate matter suspended in water and being actively transported, which is generally dominated by fine-grained inorganic sediment and small particles of organic matter. The finest grained bed sediments, with relatively high organic-matter content, also may have the potential for higher organochlorine concentrations than coarser sediments from the same location. Within about $10 \mathrm{~m}$ of each site, a location within the channel was visually selected where the deposition of fine particulate matter seemed to be favored. A sample of the top $6 \mathrm{~cm}$ of bed-sediment material was collected at the location using methods described in the following section.

\section{SAMPLING AND ANALYTICAL METHODS}

Stainless steel BMH-53 core samplers (Guy and Norman, 1970) were used to collect bed-sediment samples when the stream was wadeable. Samples from deep pooled reaches were collected using K.B.-type stainless-steel core samplers (Greeson, et al., 1977), which could be lowered from bridges or other structures. At river stations where the flow was too swift and too deep to sample either by wading or with core samplers, a BMH-60 bed-sediment sampler (Guy and Norman, 1970) fitted with a stainless steel bucket was used. Prior to use at each sampling site, equipment was thoroughly rinsed with alconox, acetone, distilled water, and then native water. Samples collected at each site were thoroughly mixed in glass or stainless steel bowls with a stainless steel implement prior to subsampling for organochlorine residues, organic carbon, and particle-size determinations. Samples were split in the field at three sites for duplicate analysis by the laboratory. Dischargeweighted samples of suspended sediment were collected using a USDH-48 sampler (Guy and Norman, 1970).

Samples for organic carbon and organochlorine residues were analyzed in the U.S. Geological Survey water-quality laboratory in Denver, Colorado. Organic carbon in bed sediment was determined by the difference between total carbon, measured by oxidizing the sample in an induction furnace, and inorganic carbon, measured by treating a sample with acid, heating it, and measuring the amount of carbon dioxide evolved. Standard reference solutions were used for quality control (Wershaw, et al., 1983). 
Organochlorine pesticide residues determined in each sample were chlordane, DDD, DDE, DDT, dieldrin, endosulfan, endrin, heptachlor, heptachlor epoxide, lindane, methoxychlor, mirex, perthane, and toxaphene. The detection limit was $10 \mu \mathrm{g} / \mathrm{kg}$ for toxaphene, $1.0 \mu \mathrm{g} / \mathrm{kg}$ for chlordane, and $0.1 \mu \mathrm{g} / \mathrm{kg}$ for the other pesticides. These pesticides were extracted from bed-sediment material with organic solvents and identified and quantified by gas chromotography using electron capture detectors. Analytical mixed-pesticide reference standards, or equivalent, were used to match peaks measured on samples. Details of analytical methods and precision are reported in Wershaw, et al. (1983). Results for duplicate samples from three sites (table 2) show the consistency of the sample splitting procedure and the chemical analyses.

Samples for grain-size determination were analyzed at the U.S. Geological Survey sediment laboratory in Salinas, California. The amount of sample particles greater than 62 micrometers in diameter was determined by sieve analysis. The particle-size distribution of sample material less than 62 micrometers in diameter was determined from the hydraulic properties of the particles and their fall velocity using the visualaccumulation tube-pipette method (Guy, 1969).

\section{CONCENTRATIONS AND DISTRIBUTION}

Results of organochlorine residue analyses are given in table 3 for bed sediments sampled at all 24 sites. Table 4 shows corresponding data for streamflow and bed- and suspended-sediment charac-
Table 2.--Concentrations of organochlorine pesticides detected in duplicate samples split in the field and submitted blind to the laboratory

[Chlordane, DDT, endrin, heptachlor, heptachlor epoxide, lindane, methoxychlor, perthane, and toxaphene were analyzed for but not detected in any of the duplicate samples]

\begin{tabular}{|c|c|c|c|c|c|c|}
\hline \multirow{2}{*}{$\begin{array}{l}\text { Site } \\
\text { No. }\end{array}$} & \multirow{2}{*}{$\begin{array}{l}\text { Sample } \\
\text { No. }\end{array}$} & \multicolumn{2}{|c|}{ Pesticide } & \multicolumn{2}{|c|}{ concentrations } & $\mu \mathrm{g} / \mathrm{kg})$ \\
\hline & & DDD & DDE & $\begin{array}{l}\text { Diel- } \\
\text { drin }\end{array}$ & $\begin{array}{l}\text { Endo- } \\
\text { sulfan }\end{array}$ & Mirex \\
\hline 14 & $\begin{array}{l}1 \\
2\end{array}$ & $\begin{array}{r}<0.1 \\
.2\end{array}$ & $\begin{array}{r}0.9 \\
.7\end{array}$ & $\begin{array}{r}<0.1 \\
<.1\end{array}$ & $\begin{array}{r}<0.1 \\
<.1\end{array}$ & $\begin{array}{l}0.1 \\
<.1\end{array}$ \\
\hline 22 & $\begin{array}{l}1 \\
2\end{array}$ & $\begin{array}{l}11 \\
10\end{array}$ & $\begin{array}{l}58 \\
43\end{array}$ & $\begin{array}{l}4.4 \\
3.6\end{array}$ & $\begin{array}{l}2.6 \\
1.9\end{array}$ & $\begin{array}{l}.4 \\
.4\end{array}$ \\
\hline 25 & $\begin{array}{l}1 \\
2\end{array}$ & $\begin{array}{l}1.6 \\
1.8\end{array}$ & $\begin{array}{l}3.9 \\
3.6\end{array}$ & $\begin{array}{l}.7 \\
.6\end{array}$ & $\begin{array}{l}.8 \\
.9\end{array}$ & $\begin{array}{l}<.1 \\
<.1\end{array}$ \\
\hline
\end{tabular}

teristics. The most frequently detected pesticides were DDD (detected at 83 percent of sites), DDE (detected at all sites), DDT (33 percent of sites), and dieldrin (58 percent of sites). Note, however, that chlordane and toxaphene had higher detection limits, and may have been detected more frequently if measured to the $0.1 \mu \mathrm{g} / \mathrm{kg}$ level. Maximum concentrations of the four most frequently detected pesticides were DDD, $260 \mu \mathrm{g} / \mathrm{kg}$; $\mathrm{DDE}, 430 \mu \mathrm{g} / \mathrm{kg}$; $\mathrm{DDT}, 420 \mu \mathrm{g} / \mathrm{kg}$, and dieldrin, $8.9 \mu \mathrm{g} / \mathrm{kg}$. Concentrations of DDD, DDE, DDT, and dieldrin were highest in westside tributaries (table 3 ). The six westside tributaries had the five highest concentrations of DDD and DDE, and the three highest concentrations of DDT and dieldrin. 
Table 3.--Concentrations of organochlorine pesticides detected in bed sediments [Endrin, heptachlor, heptachlor epoxide, lindane, methoxychlor, and perthane were analyzed for but not detected in any of the samples]

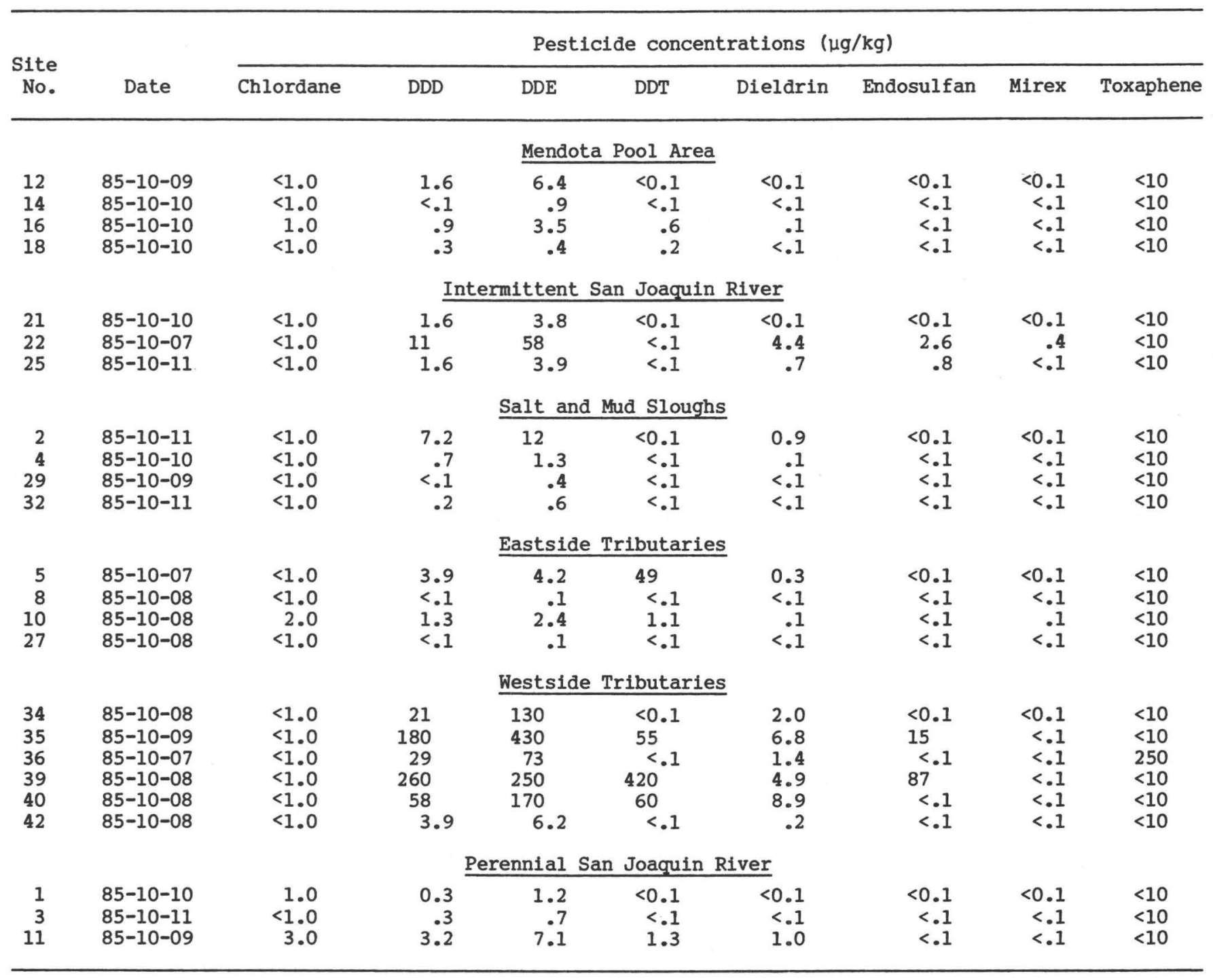


Table 4.--Streamflow and bed-and suspended-sediment characteristics

\begin{tabular}{|c|c|c|c|c|c|}
\hline \multirow[b]{2}{*}{$\begin{array}{l}\text { Site } \\
\text { No. }\end{array}$} & \multirow[b]{2}{*}{$\begin{array}{l}\text { Streamflow } \\
\left(\mathrm{m}^{3} / \mathrm{s}\right)\end{array}$} & \multicolumn{2}{|c|}{ Bed sediment } & \multicolumn{2}{|c|}{ Suspended sediment } \\
\hline & & $\begin{array}{l}\text { Total } \\
\text { organic } \\
\text { carbon } \\
\text { (percent of } \\
\text { dry weight) }\end{array}$ & $\begin{array}{l}\text { Less than } \\
62-\mu \mathrm{m} \text { size } \\
\text { fraction } \\
\text { (percent of } \\
\text { dry weight) }\end{array}$ & $\begin{array}{l}\text { Concentration } \\
(\mathrm{mg} / \mathrm{L})\end{array}$ & $\begin{array}{l}\text { Less than } \\
62-\mu \mathrm{m} \text { size } \\
\text { fraction } \\
\text { (percent of } \\
\text { dry weight) }\end{array}$ \\
\hline
\end{tabular}

Mendota Pool Area

$\begin{array}{rrrrrr}12 & <0.003 & 1.1 & 94 & 35 & 99 \\ 14 & 8.27 & .05 & 6 & 48 & 99 \\ 16 & 8.10 & .23 & 11 & 36 & 97 \\ 18 & .150 & .18 & 2 & 5 & 89\end{array}$

Intermittent San Joaquin River

$\begin{array}{rrrrrr}21 & <0.003 & 1.4 & 40 & 26 & 89 \\ 22 & <.003 & 1.3 & 95 & 134 & 97 \\ 25 & .203 & 1.7 & 97 & 115 & 98\end{array}$

Salt and Mud Sloughs

$\begin{array}{rrrrrr}2 & 3.54 & 1.4 & 67 & 155 & 98 \\ 4 & .850 & .23 & 46 & 110 & 98 \\ 29 & .266 & .46 & 59 & 157 & 100 \\ 32 & .011 & .28 & 73 & 75 & 99\end{array}$

Eastside Tributaries

$\begin{array}{rcrrrr}5 & 6.37 & 0.56 & 15 & 44 & 69 \\ 8 & 5.95 & .08 & 1 & 15 & 88 \\ 10 & 12.3 & .55 & 21 & 20 & 80 \\ 27 & 6.77 & .10 & 4 & 79 & 96\end{array}$

Westside Tributaries

\begin{tabular}{|c|c|c|c|c|c|}
\hline 34 & 0.433 & 1.2 & 60 & 145 & 99 \\
\hline 35 & 2.01 & .55 & 57 & 118 & 93 \\
\hline 36 & .003 & .66 & 40 & 24 & 98 \\
\hline 39 & .011 & 1.1 & 90 & 18 & 97 \\
\hline 40 & .181 & .57 & 68 & 466 & 95 \\
\hline 42 & .133 & .56 & 15 & 36 & 97 \\
\hline \multicolumn{6}{|c|}{ Perennial San Joaquin River } \\
\hline 1 & 7.02 & 0.69 & 24 & 74 & 70 \\
\hline 3 & 11.4 & .18 & 8 & 121 & 85 \\
\hline 11 & 52.4 & .34 & 32 & 96 & 93 \\
\hline
\end{tabular}


Concentrations of DDD, DDE, DDT, and dieldrin were generally correlated with each other (table 5). Concentrations of DDD, DDE, and DDT are usually correlated because the occurrence of all three is related mainly to DDT use (for example, see Hill and Wright, 1978). Most use of DDT had ended by 1970, when pesticide-use records were first kept in California. Therefore, we have only anectdotal knowledge that use in the general study area was substantial. Though DDP was applied directly as a pesticide in some areas, it is also a product of the degradation of DDT. DDE is a degradation product of DDT and both DDE and DDT are residual products in the manufacture of dicofol (Mischke, et al., 1985), a pesticide which is still in use. Thus, small quantities of DDE and DDT are still inadvertently applied in some places. Because of the degree of correlation between DDD, DDE, DDT, and dieldrin, and because DDE was the only pesticide detected at all sites, DDE was focused upon for more detailed analysis. DDD, DDT, and dieldrin were found to follow the same general relations with sediment characteristics as DDE.

Table 5.--Correlation matrix for $D D D$, $D D E, D D T$, and dieldrin at all 24 sites

[Values are for the correlation coefficient, $r$, for the logarithms of concentrations. All correlations are significant at $\alpha=0.05$. For concentrations less than the detection limit of $0.1 \mu \mathrm{g} / \mathrm{kg}$, a value of $0.05 \mu \mathrm{g} / \mathrm{kg}$ was assigned only for this analysis]

\begin{tabular}{lrrr}
\hline \multirow{2}{*}{ Pesticide } & \multicolumn{3}{c}{ Correlation of logarithms } \\
\cline { 2 - 4 } & DDD & DDE & DDT \\
\hline DDE & & -- & -- \\
DDT & 0.97 & 0.57 & -- \\
Dieldrin & .66 & .87 & 0.58 \\
\hline
\end{tabular}

The present-day areal distribution of DDE residues in bed sediments of the San Joaquin River basin probably reflects a combination of (1) the distribution of soils and bed sediments with characteristics that favor the presence of high concentrations; (2) hydrologic characteristics which have determined the residence time or origin of particles and associated pesticides in the hydrologic system, and (3) historical pesticide use. Chiou (1987) has shown, by extensive study and review of work by other researchers, that pesticides generally partition into organic matter in aquatic sediments. Concentrations of DDE in bed sediments of the San Joaquin River system are significantly $(\alpha=0.05)$ correlated with the amount of total organic carbon (TOC) present (fig. 2). Because of the close relation between TOC and the amount of sample less than 62 micrometers in diameter ( $<62-\mu \mathrm{m}$ size fraction), as shown in figure 3, DDE also is similarly correlated with the $<62-\mu \mathrm{m}$ size fraction $\left(r^{2}=0.35\right.$ for log-log correlation).

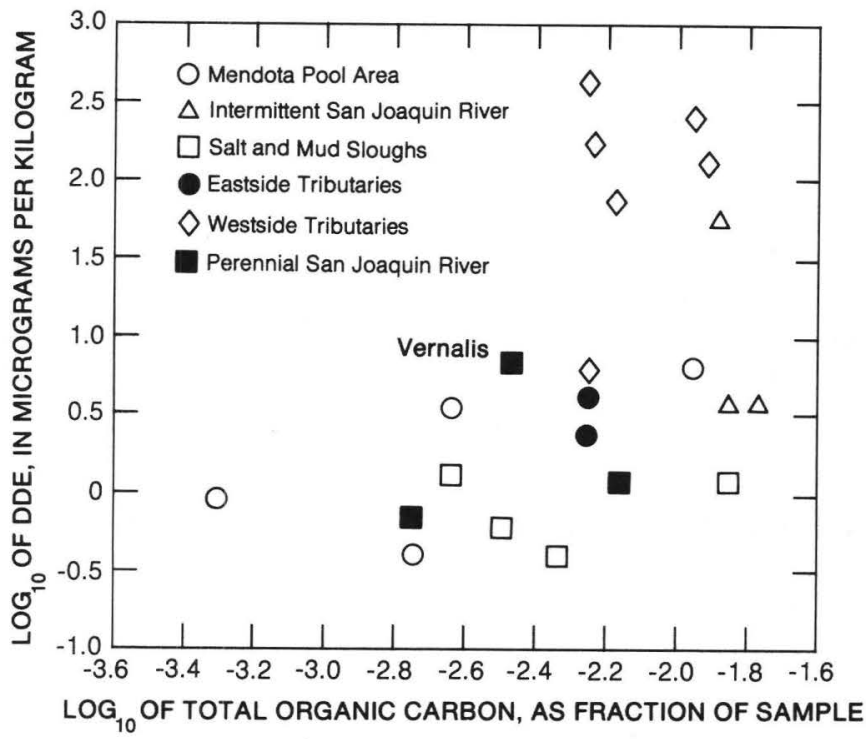

FIGURE 2. -- Relation between DDE concentrations in bed sediments and total organic carbon $\left(r^{2}=0.35\right)$. 


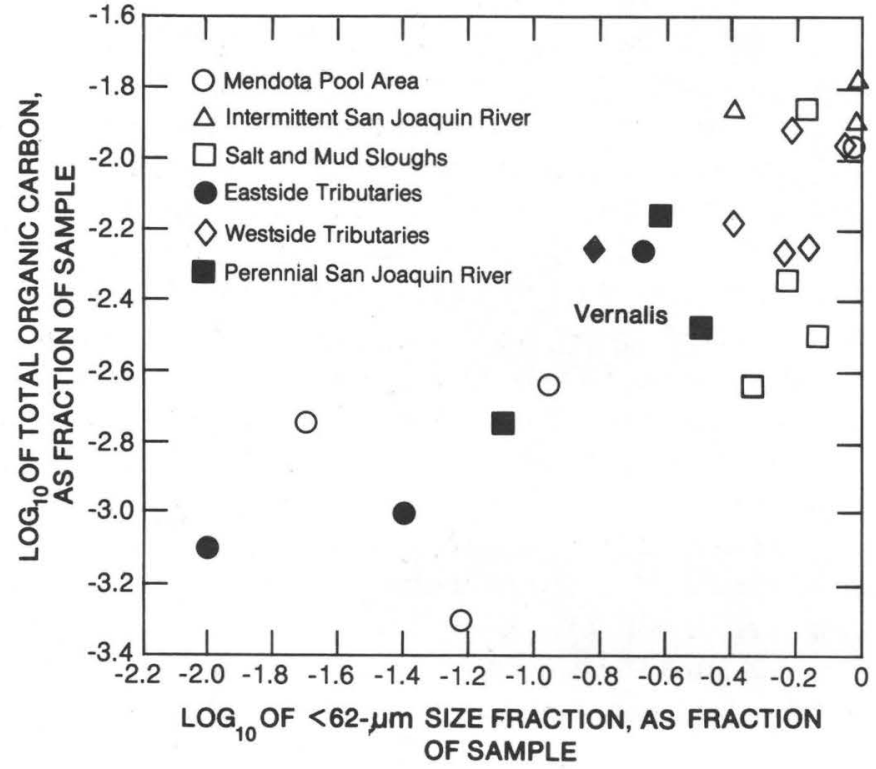

FIGURE 3. -- Relation between total organic carbon and $<62-\mu \mathrm{m}$ size fraction $\left(r^{2}=0.64\right)$.

Figure 2 shows that some site groups are characterized by a fairly consistent range of DDE and/or TOC concentrations. However, after standardizing DDE concentrations by dividing by TOC, only sites on westside tributaries had clearly different DDE levels than all other site groups. Figure 4 illustrates this distinction by boxplots of the ratio of DDE to TOC. This is important because it indicates that the higher $\mathrm{DDE}$ concentrations in westside tributaries are not due solely to different sediment characteristics.

The relative enrichment of westside tributary sediments in DDE compared to sites in other areas may be due to either greater historical use of DDT or to the nature of the hydrologic system in that area. The agricultural area drained by the westside tributaries has been farmed since the early 1900's, and was intensely farmed during the period when DDT was commonly used on many of the crops grown

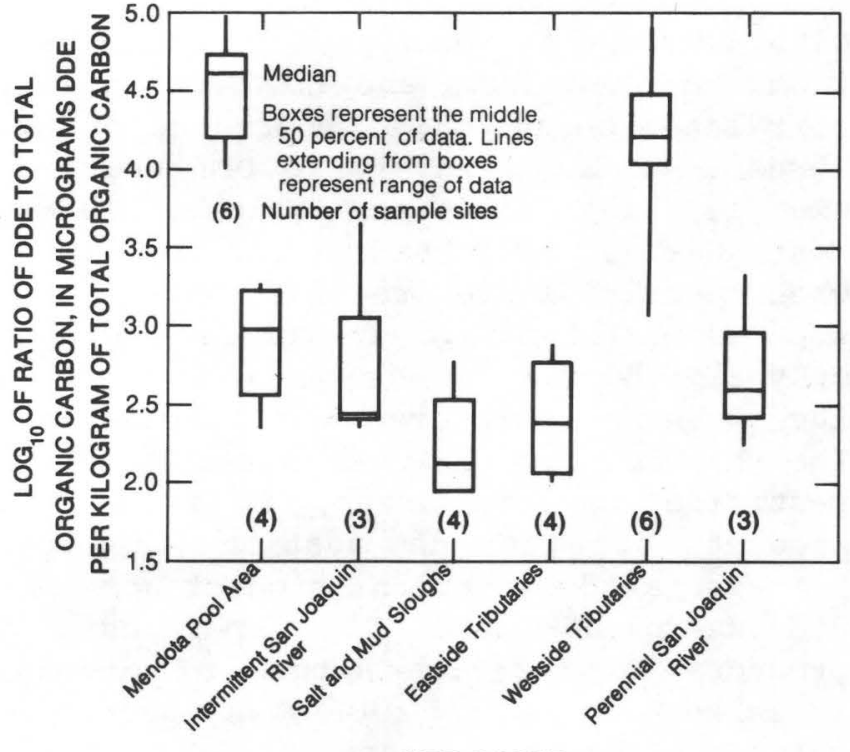

SITE GROUP

FIGURE 4. -- Distribution of DDE concentrations after standardizing by total organic carbon.

there. In addition, the water carried by the westside tributaries consists mostly of surface runoff from irrigated fields.

Though the area drained by salt and Mud sloughs is also in the western valley, it is much different from the areas drained by the westside tributaries. Much of that low-lying area is managed as wetland and pasture so that historical DDT use would have been minimal. In addition, part of the water that reaches Salt and Mud Sloughs from nearby croplands is subsurface drainage, which does not have as great a potential to transport organochlorine residues as surface runoff does because it has filtered through soil at very low velocities and generally does not contain particulate matter.

Although tributaries in different parts of the San Joaquin River drainage developed different bed-sediment characteristics and degrees of enrichment in DDE and 
other organochlorine residues, the varying water and sediments ultimately mix in the San Joaquin River. Bed sediments in the river near vernalis, downstream of all tributaries assessed, show the apparent affect of the mixing process. As illustrated in figure 2, bed sediments at Vernalis have both TOC and DDE concentrations intermediate among the various tributaries.

\section{LOADING TO THE RIVER}

Loading of organochlorine pesticides to the San Joaquin River can be indirectly estimated from flow and suspendedsediment concentrations measured at each site where bed sediments were sampled. The instantaneous load of a pesticide associated with sediment was calculated from

$$
L_{E}=Q \cdot S S \cdot C \cdot K
$$

where

$$
\begin{aligned}
& L_{E} \text { is estimated load, in } \mathrm{kg} / \mathrm{d} ; \\
& Q \text { is flow, in } \mathrm{m}^{3} / \mathrm{s} ; \\
& S S \text { is suspended-sediment concen- } \\
& \text { tration, in } \mathrm{mg} / \mathrm{L} ; \\
& C \text { is bed-sediment pesticide concen- } \\
& \text { tration, in } \mu \mathrm{g} / \mathrm{kg} \text {; and } \\
& K \text { is a unit conversion factor of } \\
& 2.419 \cdot 10^{-9} \text {. }
\end{aligned}
$$

Equation 1 is based on the assumptions that (1) suspended sediment has identical pesticide concentrations as bed sediments that were sampled, and (2) dissolved forms of the pesticides are insignificant. Many of the bed sediments sampled consisted of substantially less than 90 percent of the $<62-\mu \mathrm{m}$ size fraction, compared to usually more than 90 percent for suspended sediment (table 3 ). Though TOC was not measured in suspended sediment, the correlation between TOC and the $<62-\mu \mathrm{m}$ size fraction indicates that suspended sediments probably have similarly greater TOC concentrations than bed sediments. Thus, bed-sediment analyses may be an underestimate of organochlorine concentrations in suspended sediment. But, suspended sediments may be dominated by particles from more recent erosion than the bed sediment, which may or may not have similar pesticide concentrations. Samples were purposely taken from areas where deposition of fine-grained material is favored. The assumption that dissolved forms are insignificant is likely valid. Organochlorine residues are only slightly soluble and are seldom found in dissolved forms.

Clearly, estimates of pesticide residue loading from equation 1 are not actual measured loads to the river, but are only an indication of the relative importance of loading of organochlorines from the different tributaries at the time they were measured. Equation 1 was used to estimate the load of each of the most frequently detected residues--DDD, DDE, DDT, and dieldrin--for each tributary where bed sediments were sampled, and near Vernalis, the farthest downstream site on the San Joaquin River. Each estimated tributary load was divided by the computed load at Vernalis to express the loads on a relative scale (table 6). The relative loadings indicate that at the time of this study most loading of DDD, DDE, DDT, and dieldrin to the San Joaquin River generally was from westside tributaries, particularly Orestimba and Hospital Creeks. The relative loads of DDD, DDE, and DDT at Orestimba Creek and DDT at the Merced River substantially exceed 1.0, indicating some combination of load estimation error, in-channel losses downstream, or simply unsteady transport conditions. Further study should focus on verifying the loads by direct measurement of suspended-phase transport over time. 
Table 6.--Estimated tributary loads of $D D D, D D E, D D T$, and dieldrin relative to the estimated load near Vernalis

[Loads were computed using equation 1, and divided by the Vernalis load. Values not computed because the concentration was less than the detection limit are indicated by nd]

\begin{tabular}{|c|c|c|c|c|}
\hline \multirow{2}{*}{$\begin{array}{c}\text { Site } \\
\text { No. }\end{array}$} & \multicolumn{4}{|c|}{$\begin{array}{l}\text { Estimated relative load } \\
\text { (fraction of estimated Vernalis load) }\end{array}$} \\
\hline & DDD & DDE & $\mathrm{DDT}$ & Dieldrin \\
\hline \multicolumn{5}{|c|}{ Salt and Mud Sloughs } \\
\hline $\begin{array}{r}2 \\
4 \\
32\end{array}$ & $\begin{array}{r}0.01 \\
.00 \\
.00\end{array}$ & $\begin{array}{r}0.02 \\
.00 \\
.00\end{array}$ & $\begin{array}{l}\text { nd } \\
\text { nd } \\
\text { nd }\end{array}$ & $\begin{array}{r}0.10 \\
\text { nd } \\
\text { nd }\end{array}$ \\
\hline \multicolumn{5}{|c|}{ Eastside Tributaries } \\
\hline $\begin{array}{r}5 \\
8 \\
10\end{array}$ & $\begin{array}{r}0.07 \\
\text { nd } \\
.02\end{array}$ & $\begin{array}{r}0.03 \\
.00 \\
.02\end{array}$ & $\begin{array}{r}2.1 \\
\text { nd } \\
.04\end{array}$ & $\begin{array}{r}0.02 \\
\text { nd } \\
.00\end{array}$ \\
\hline \multicolumn{5}{|c|}{ Westside Tributaries } \\
\hline $\begin{array}{l}34 \\
35 \\
36 \\
39 \\
40 \\
42\end{array}$ & $\begin{array}{c}0.08 \\
2.7 \\
.00 \\
.00 \\
.30 \\
.00\end{array}$ & $\begin{array}{c}0.23 \\
2.9 \\
.00 \\
.00 \\
.40 \\
.00\end{array}$ & $\begin{array}{c}\text { nd } \\
2.0 \\
\text { nd } \\
.01 \\
.78 \\
\text { nd }\end{array}$ & $\begin{array}{r}0.02 \\
.32 \\
.00 \\
.00 \\
.15 \\
.00\end{array}$ \\
\hline \multicolumn{5}{|c|}{ Perennial San Joaquin River } \\
\hline 1 & 0.01 & 0.02 & nd & nd \\
\hline
\end{tabular}

\section{ENVIRONMENTAL SIGNIFICANCE}

The environmental significance of the bed-sediment concentrations of pesticides measured can only be indirectly assessed because there are no water-quality criteria for organochlorine residues in bed-sediment material. However, earlier cited findings that levels of the $\Sigma D D T$ have recently been found at undesirable levels in fish from the San Joaquin River indicate that present-day concentrations may be cause for concern.
One indirect approach to assessing the potential significance of the concentrations measured is to estimate the total concentration of each pesticide in water from the suspended-sediment concentration measured at each site.

$$
C_{E}=S S \cdot C \cdot K
$$

where

$C_{E}$ is estimated pesticide concen-
tration in water, in $\mu \mathrm{g} / \mathrm{L} ;$

SS is suspended-sediment concentration, in $\mathrm{mg} / \mathrm{L}$;

$C$ is bed-sediment pesticide concentration in $\mu \mathrm{g} / \mathrm{kg}$; and

$K$ is a unit conversion factor of

$$
10^{-6} \text {. }
$$

This is similar to the relative loading calculation (eq. 1) and also relies on the assumptions that there are no dissolved forms of the pesticides present in the water and that organochlorine pesticide concentrations in the bed materials sampled are similar to concentrations in suspended sediment. Suspended-sediment concentration is simply multiplied by the concentration of each pesticide in bed material.

Resulting concentration estimates are listed in table 7 for all samples with detectable organochlorine residues for which there are established water-quality criteria, including $\Sigma$ DDT. The sum of computed concentrations of the DDD, DDE, and DDT exceeded the aquatic-life waterquality criterion of $0.001 \mu \mathrm{g} / \mathrm{L}$ at 9 of the 24 sites. The four highest concentrations were in westside tributaries, with a maximum concentration of 0.134 $\mu \mathrm{g} / \mathrm{L}$ EDDT in Hospital Creek (site 40). 
Table 7.--Comparison of estimated water concentrations of detected organochlorine pesticides to water-quality criteria for aquatic life

[Estimated concentrations were computed from equation 2. The criterion for the DDT family of compounds is expressed as the sum of DDD, DDE, and DDT, denoted as EDDT. All criteria are from U.S. Environmental Protection Agency (1986), and are for acceptable 24-hour average concentrations in water. Values that exceed criteria are underlined and "nd" is indicated where the compound was not detected in the bed-sediment sample]

\begin{tabular}{|c|c|c|c|c|c|c|}
\hline \multirow{2}{*}{$\begin{array}{l}\text { Site } \\
\text { No. }\end{array}$} & \multicolumn{6}{|c|}{ Estimated water concentration $(\mu \mathrm{g} / \mathrm{L})$} \\
\hline & Chlordane & $\sum \mathrm{DDT}$ & Dieldrin & Endosulfan & Mirex & Toxaphene \\
\hline \multicolumn{7}{|c|}{ Aquatic-life criterion } \\
\hline & 0.004 & 0.001 & 0.002 & 0.056 & 0.001 & 0.013 \\
\hline \multicolumn{7}{|c|}{ Mendota Pool Area } \\
\hline 12 & nd & 0.000 & nd & nd & nd & nd \\
\hline 14 & nd & .000 & nd & nd & nd & nd \\
\hline 16 & 0.000 & .000 & 0.000 & nd & nd & nd \\
\hline 18 & nd & .000 & nd & nd & nd & nd \\
\hline \multicolumn{7}{|c|}{ Intermittent San Joaquin River } \\
\hline 21 & nd & 0.000 & nd & nd & nd & nd \\
\hline 22 & nd & .009 & 0.001 & 0.000 & 0.000 & nd \\
\hline 25 & nd & $\overline{.001}$ & .000 & .000 & .000 & nd \\
\hline \multicolumn{7}{|c|}{ Salt and Mud Sloughs } \\
\hline 2 & nd & 0.000 & 0.000 & nd & nd & nd \\
\hline 4 & nd & .000 & nd & nd & nd & nd \\
\hline 29 & nd & .000 & nd & nd & nd & nd \\
\hline 32 & nd & .000 & nd & nd & nd & nd \\
\hline \multicolumn{7}{|c|}{ Eastside Tributaries } \\
\hline 5 & nd & 0.003 & 0.000 & nd & nd & nd \\
\hline 8 & nd & .000 & nd & nd & nd & nd \\
\hline 10 & nd & .000 & .000 & nd & nd & nd \\
\hline 27 & nd & .000 & nd & nd & nd & nd \\
\hline \multicolumn{7}{|c|}{ Westside Tributaries } \\
\hline 34 & nd & 0.022 & 0.000 & nd & nd & nd \\
\hline 35 & nd & .079 & .001 & 0.002 & nd & nd \\
\hline 36 & nd & .002 & .000 & nd & nd & nd \\
\hline 39 & nd & $\overline{.017}$ & .000 & .002 & 0.000 & 0.006 \\
\hline 40 & nd & $\overline{.134}$ & .004 & nd & nd & nd \\
\hline 42 & nd & $\overline{.000}$ & $\overline{.000}$ & nd & nd & nd \\
\hline \multicolumn{7}{|c|}{ Perennial San Joaquin River } \\
\hline 1 & 0.000 & 0.000 & nd & nd & nd & nd \\
\hline 3 & nd & .000 & nd & nd & nd & nd \\
\hline 11 & .000 & .001 & 0.000 & nd & nd & nd \\
\hline
\end{tabular}


Hospital Creek also had the highest computed water concentration of dieldrin at $0.004 \mu \mathrm{g} / \mathrm{L}$, which was the only exceedance of water-quality criteria other than for IDDT .

Estimated concentrations of LDDT in the San Joaquin River itself were mostly low. Samples from five sites $(14,16,18,21$, 22) on reaches of the river upstream from Stevinson yielded estimated concentrations below the criterion except for site 22 , for which $0.009 \mu \mathrm{g} / \mathrm{L}$ was computed. Bed-sediment concentrations measured at sites on the perennial part of the San Joaquin River yielded estimated concentrations below criteria at the two upstream sites ( 1 and 3 ), but equal to the EDDT criterion at Vernalis (site 11), the site farthest downstream. The Vernalis site is the only river site downstream from the westside tributaries.

These computed concentrations in water indicate the potential for actual concentrations to exceed established criteria. They indicate where the potential is greatest, and thus where direct measurements most need to be made.

\section{CONCLUSIONS}

Residues of the DDT family of organochlorine pesticides (DDD, DDE, and DDT) and dieldrin are widespread in finegrained bed sediments of the San Joaquin River and its tributaries despite little or no use of these pesticides for more than a decade. Concentrations of all four pesticides were correlated with each other and with the amount of organic carbon in the bed sediments. The highest concentrations occurred in the bed sediments of westside tributary streams.

Estimated loadings of DDD, DDE, DDT and dieldrin residues from tributaries to the San Joaquin River indicate that most of the loading to the river at the time of the study was probably from the westside tributaries. Estimated water concentrations also were computed for each pesticide from the bed-sediment and suspendedsediment concentrations at each site. These estimated water concentrations exceeded the aquatic-life criterion for EDDT (the sum of DDD, DDE, and DDT) of $0.001 \mu \mathrm{g} / \mathrm{L}$ at 9 of the 24 sites sampled. Five of the nine sites are westside tributaries and one is the San Joaquin River near Vernalis.

The high concentrations of EDDT in the bed sediments of the westside tributaries and likely in the surrounding soils are a potential long-term source of these contaminants to the San Joaquin River. This possibility could be evaluated by a direct assessment of the transport of pesticides with the suspended sediment that enters the river from these small streams and with the suspended sediment transported by the San Joaquin River to Vernalis and the delta area. 


\section{LITERATURE CITED}

Bailey, T.E., and J.R. Hannum, 1967. Distribution of pesticides in California. J. Saint, Engineering Division Proceedings, American Society of Civil Engineers, v. 93, pp. 27-43.

California Department of Food and Agriculture, 1977. Pesticide use report--annual 1977. State of California, $194 \mathrm{pp}$.

Chiou, C.T., 1987. Roles of organic matter, minerals, and moisture sorption on monionic compounds and pesticides by soil. In: Humic substances in soil and crop sciences, American Agronomy Society.

Gilliom, R.J., R.B. Alexander, and R.A. Smith, 1985. Pesticides in the Nation's rivers, 19751980, and implications for future monitoring. U.S. Geological Survey Water-Supply Paper 2271, $26 \mathrm{pp}$.

Greeson, P.E., T.A. Ehlke, G.A. Irwin, B.W. Lium, and K.V. Slack, 1977. Methods for collection and analysis of aquatic biological and microbiological samples. U.S. Geological Survey Techniques of Water-Resources Investigations, Book 5, Chapter A4, 332 pp.

Guy, H.P., 1969. Laboratory theory and methods for sediment analysis. U.S. Geological Survey Techniques of Water-Resources Investigations, Book 5, Chapter $\mathrm{Cl}, 58 \mathrm{pp}$.

Guy, H.P., and V.W. Norman, 1970. Methods for measurement of fluvial sediment. U.S. Geological Survey Techniques of Water-Resources Investigations, Book 3, Chapter C2, 59 pp.

Hill, I.R., and S.J. Wright, 1978. Pesticide microbiology. New York, Academic Press, 844 pp.

Hunt, E.S., 1964. Fish population surveys in agricultural drains. California Department of Fish and Game, job completion report FW-1-R-1, workplan III, job I, 3 pp.

LaCaro, F., 1983. Toxic substances monitoring program--1982. California State Water Resources Control Board, Water-Quality Monitoring Report No. 83-7TS, $37 \mathrm{pp}$.
LaCaro, F., S.P. Hayes, D. Watkins, and C. Pliner, 1982. Toxic substances monitoring program-1981. California State Water Resources Control Board, Water-Quality Monitoring Report No. 82-3TS, 55 pp.

Lavenda, T.E., 1982. Water quality inventory for water years 1980 and 1981. California State Water Resources Control Board, Water-Quality Monitoring Report No. 82-1TS, 320 pp.

Linn, J.D., Catherine Reiner, David Crane, Lawrie Smith, and Warren Seto, 1986. Toxic substances monitoring program 1985 data report: California State Water Resources Control Board, Laboratory Report No. 86-1, 34 p. and appendices.

Mischke, Tom, Kathy Brunetti, Vic Acosta, Don Weaver, and Mary Brown [Editors], 1985. Agricultural sources of DDT residues in California's environment. Environmental Hazards Assessment Program, California Department of Food and Agriculture, $42 \mathrm{pp}$.

National Academy of Sciences, National Academy of Engineering, 1973. Water-Quality Criteria; 1972. U.S. Environmental Protection Agency, EPA-R3-73-033, Washington, D.C., 594 pp.

Saiki, M.K., and C.J. Schmitt, 1986. Organochlorine chemical residues in bluegills and common carp from the irrigated San Joaquin Valley floor, California: Arch. Environmental Contamination Toxicol., v. 15, pp. 357-366.

U.S. Environmental Protection Agency, 1985. Technical support document for water quality-based toxics control. U.S. Environmental Protection Agency, EPA-440/4-85-032, 74 pp.

U.S. Environmental Protection Agency, 1986. Quality criteria for water, 1986. U.S. Environmental Protection Agency, EPA-440/5-86-001, various pagination.

Wershaw, R.L., M.J. Fishman, R.R. Grabbe, and L.E. Lowe [Editors], 1983. Methods for the determination of organic substances in water and fluvial sediments: U.S. Geological Survey Techniques of Water-Resources Investigations, Book 5, Laboratory Analysis, Chapter A3; or Open-File Report 82-1004, 173 pp. 
GIIIIOM and Clifton--PESTICIDE RESIDUES IN BED SEDIMENTS, SAN JOAQUIN RIVER AND ITS TRIBUTARY STREAMS, CALIFORNIA--OFR 87-531 